\title{
Admixture Mapping Links RACGAP1 Regulation to Prostate Cancer in African Americans
}

\author{
BRADFORD D. WILSON ${ }^{1}$, LUISEL J. RICKS-SANTI ${ }^{2}$, TSHELA E. MASON ${ }^{1}$, MUNEER ABBAS $^{1,3}$, \\ RICK A. KITTLES ${ }^{4}$, GEORGIA M. DUNSTON ${ }^{1,3}$ and YASMINE M. KANAAN ${ }^{3}$ \\ ${ }^{1}$ National Human Genome Center, Howard University, Washington, DC, U.S.A.; \\ ${ }^{2}$ Cancer Research Center, Hampton University, Hampton, VA, U.S.A.; \\ ${ }^{3}$ Department of Microbiology, Howard University, Washington, DC, U.S.A.; \\ ${ }^{4}$ City of Hope Comprehensive Cancer Center, Duarte, CA, U.S.A.
}

\begin{abstract}
Background/Aim: Prostate cancer is the most common malignancy in US males. African American men have higher incidence and mortality rates than European Americans. Five single nucleotide polymorphisms are associated with PCa. We hypothesized haplotypes inferred from these SNPs are also associated with PCa. Patients and Methods: We genotyped SNPs in a case-control admixture mapping study. SNP haplotypes inferred for 157 PCa cases and 150 controls were used in the regression analysis. Results: We found an association between "GTCCC", "ATTCT", and "ACCCC" haplotypes and PCa after ancestry adjustment $(O R=3.62$, $95 \% C I=1.42-9.21, p=0.0070 ; O R=7.89,95 \% C I=2.36-26.31$, $p=0.0008 ; \quad O R=4.34,95 \% C I=1.75-10.78, p=0.0016)$. The rs615382 variant disrupts the recombination signal binding protein with immunoglobulin kappa $J$ binding site in Rac GTPase activating protein 1 (RACGAP1). Conclusion: Disruption of notch 1 mediated-repression of RACGAP1 may contribute to PCa in African Americans.
\end{abstract}

Prostate cancer (PCa) is the third most prevalent cancer in the world after breast and colorectal cancers, and the most common cancer affecting men in the US (1-9). PCa incidence and mortality rates are disproportionately higher among African American (AA) men compared to their European American counterparts (2-9). This disparity is greatest in the nation's capital, Washington D.C., which has

This article is freely accessible online.

Correspondence to: Bradford D. Wilson, National Human Genome Center, Cancer Center, Howard University, 2041 Georgia Ave, NW Suite 615 Washington DC, 20059, U.S.A. Tel: +1 3013567864, Fax: +1 2029863972, e-mail: bradford.wilson@howard.edu

Key Words: Prostate cancer, African Americans, RACGAP1. the highest incidence and mortality rates in the country (10). It is unclear what factors account for the observed disparities. Risk factors for PCa include age, race/ethnicity, family history and environmental factors; however, a strong genetic association has yet to be identified (11-13). The observed disparities warrant the use of an approach that leverages allele frequency differences to identify loci contributing to disease pathology.

The approaches and methods used to identify genes that are causal or predispose an individual to PCa have evolved over time. Early efforts studied the disease in familial clusters and twin cohorts (13-24). Study designs then shifted to case-control and candidate gene studies. This shift was facilitated by the completion of the working draft of the genome map, a deliverable of the Human Genome Project. Advances in genotyping technology and the availability of the genome map facilitated the use of single nucleotide polymorphisms (SNPs) in association studies. The International HapMap project leveraged the information provided in the patterns of linkage disequilibrium (LD) to enhance SNP association studies. The differences observed in SNP allele frequencies between populations were later used as a tool in admixture mapping (24-29). Genome-wide association studies (GWAS) have become the standard for SNP association (30-34). Additionally, PCa GWAS results have been pooled in meta-analyses, reanalyzed using new statistical tools and re-sequenced in attempts to replicate findings (35-39).

To date over 70 variant loci have been implicated in PCa etiology via admixture mapping and GWAS (24-39). However, the identified loci do not appear to account for a majority of genetic susceptibility to PCa. In addition, these findings have not been reported with a high degree of consistency. A screening of 21 AIMs (Ancestry Informative Markers) on chromosome 12 identified a cancer susceptibility locus for PCa in African American men (29). A larger follow- 
up study was conducted to explore the findings of the screening and the results were published by Ricks-Santi et al. (40) The data from the follow-up study were re-examined to investigate the biological nature of the statistical association. Local and regional patterns of LD, evidence of selective pressure, and disruption of regulatory sequence motifs were among the local sequence features interrogated in this study.

\section{Patients and Methods}

Study population. We selected 157 AA men who were older than 40 years of age from the Washington, DC area with histologically diagnosed adenocarcinoma of the prostate, prostate specific antigen (PSA) of $>4.0 \mathrm{ng} / \mathrm{ml}$, and a positive digital rectal examination (DRE). We then identified 150 ethnicities matched (AA) controls who were regularly screened with PSA levels $<4.0 \mathrm{ng} / \mathrm{ml}$, normal DRE and with no history of PCa among first-degree relatives. PSA values and blood samples were obtained at the time of diagnosis for case subjects and at the time of study enrollment for control subjects. Participants were recruited for a Howard University Institutional Review Board (IRB) approved study through the Division of Urology at the Howard University Hospital (HUH) and from the free prostate cancer screening program at the Howard University Cancer Center (HUCC) from 2000 to 2004.

AIMs selection and genotyping. We selected a total of 21 AIMs on 12 p12-q14 to cover an average of $25 \mathrm{Mb}$ upstream and/or downstream of VDR (vitamin D receptor). Allele frequency differences between putative parental populations for African Americans (West African and European) parental populations for all AIMs was $>0.30$ (based on HapMap data). Genomic DNA extraction was performed on whole blood using the Gentra Puregene Blood Kit (Qiagen, Hilden, Germany) in accordance with the manufacturer's instructions. DNA from $157 \mathrm{PCa}$ and 150 control subjects was genotyped to study the association of 21 AIMs with PCa risk. Polymerase chain reaction (PCR) and pyrosequencing primers were designed using PyroMark Assay Design software ver. 20.0 (Qiagen, Hilden, Germany). DNA samples were polymerase chain reaction (PCR)-amplified using whole-genome amplified DNA, forward and reverse primers, $\mathrm{MgCl} 2$, deoxy-nucleotide triphosphates and platinum Taq DNA polymerase (Invitrogen, Grand Island, NY, USA). Results were analyzed with the PyroMark Q24 software (Qiagen, Hilden, Germany). Duplicate test samples and negative controls were included in each 96-well plate.

Association analysis. The association of disease status with AIM genotype and haplotype was analyzed by binary logistic regression using the R statistical software (version 2.9.0) (Vienna, Austria) and SAS/STAT version 9.1 (SAS Institute, Cary, NC, USA) software packages. Fisher's exact test and $\chi^{2}$ analysis were used to test the alleles for Hardy-Weinberg equilibrium in controls when appropriate. For this study, the major allele found in people of African descent was considered the reference allele. For each SNP genotype the dominant, co-dominant, recessive and log-additive genetic models were conducted. Confidence intervals (CIs) of $95 \%$ were set on the odds ratios (ORs) calculated after adjusting for age and ancestry. Two sided $p$-values of $\leq 0.05$ were considered to be statistically significant. The adjustment for multiple comparisons was made using the Bonferroni test.
Table I. Study participant descriptive statistics.

\begin{tabular}{lccc}
\hline Characteristics & Cases & Controls & $p$-Value \\
\hline Number of participants & 157 & 150 & - \\
Mean Age $( \pm$ SD) & $65.6( \pm 9.1)$ & $56.0( \pm 14.6)$ & $<0.001$ \\
Mean PSA level $( \pm$ SD) & $51.8( \pm 180.9)$ & $3.5( \pm 13.8)$ & $<0.001$ \\
Mean \% West African ancestry & 73.0 & 67.0 & 0.047 \\
\hline
\end{tabular}

Genetic ancestry estimation. West African ancestry was estimated in cases and controls using AIMs to control for population stratification. Individual ancestry was determined for each participant using the genotype data from the original 21 AIMs listed in Table I. Global individual ancestry (\% West African and \% European) was calculated from the genotype data using the Bayesian Markov Chain Monte Carlo method implemented in the program STRUCTURE 2.1.24 These ancestry estimates were used as covariates in the regression models.

Additional analyses. Haplotypes that were inferred using fastPHASE version 2.1 from the AIMs which showed an association with PCa after application of dominant, co-dominant, recessive, and logadditive genetic models (41). For AIMs located in putative promoter or other non-coding regions, Alibaba 2.1 (BIOBASE, Beverly, MA, USA) and HaploReg (HaploReg v3, Broad Institute of MIT, Boston MA) programs were used to identify whether variants disrupted or created regulatory factor binding sites. SNP@Evolution and dbCLINE were used to test for the evidence of selection and association with environmental factors respectively (42-44).

\section{Results}

The demographic, clinical, and ancestry data of the human subjects are shown in Table I. The student's $t$-test reveals significant differences in age between the PCa and control subjects $(p<0.001)$. The mean age of patients with $\mathrm{PCa}$ $(65.6 \pm 9.1)$ was significantly older than the controls (56.0 \pm 14.6$)$. The mean PSA levels were significantly higher in PCa patients $(51.8 \pm 180.9)$ than the controls $(3.5 \pm 13.8)$ $(p<0.001)$. The percentage of West African Ancestry was significantly different between PCa (73.0) cases and controls (67.0) $(p<0.047)$.

Association between AIMs and PCa risk. The studied AIMs were in Hardy-Weinberg equilibrium $(p<0.05)$. The allele frequencies in $\mathrm{PCa}$ patients were similar to the controls (Table II). Five (rs1993973, rs1561131, rs1843321, rs1963562, and rs615382) of the twenty-one AIMs studied were found to be associated with PCa using the four genetic models $(p<0.05)$ (Table III). AIM rs1993973 was found to be associated with PCa risk under the five genetic models; AIM rs1561131 under the co-dominant and recessive models; AIM rs1843321 only under the log-additive model; AIM rs1963562 under the dominant model only; and AIM 
Table II. Description of the studied 21 AIMs and their allele frequency in the PCa cases and controls.

\begin{tabular}{|c|c|c|c|c|c|c|c|}
\hline AIMs & Chromosomal position (bp) & Gene & Location & Major/Minor alleles & Delta & Cases & Controls \\
\hline rs989278 & 23773750 & SOX5 & intron 7 & $\mathrm{C} / \mathrm{G}$ & 0.08 & 0.34 & 0.33 \\
\hline *rs1993973 & 26201374 & - & - & $\mathrm{G} / \mathrm{A}$ & 0.63 & 0.45 & 0.38 \\
\hline rs 1027089 & 26362337 & - & - & $\mathrm{C} / \mathrm{G}$ & 0.33 & 0.16 & 0.14 \\
\hline rs895964 & 26749333 & $I T P R 2$ & intron 10 & $\mathrm{G} / \mathrm{A}$ & 0.36 & 0.21 & 0.26 \\
\hline rs 1010096 & 27735497 & $P P F I B P 1$ & intron 28 & $\mathrm{C} / \mathrm{T}$ & 0.32 & 0.44 & 0.43 \\
\hline *rs1561131 & 29199198 & - & - & $\mathrm{C} / \mathrm{T}$ & 0.39 & 0.52 & 0.48 \\
\hline$*_{\mathrm{rs} 1843321}$ & 30245161 & - & - & $\mathrm{C} / \mathrm{T}$ & 0.57 & 0.37 & 0.41 \\
\hline *rs1963562 & 36949163 & - & - & $\mathrm{C} / \mathrm{T}$ & 0.39 & 0.11 & 0.10 \\
\hline rs870431 & 37239340 & - & - & $\mathrm{A} / \mathrm{G}$ & 0.55 & 0.15 & 0.14 \\
\hline rs278906 & 39704904 & CNTN1 & intron 21 & $\mathrm{C} / \mathrm{T}$ & 0.24 & 0.17 & 0.23 \\
\hline rs 180438 & 45473527 & SLC $38 A 4$ & intron 2 & $\mathrm{G} / \mathrm{A}$ & 0.67 & 0.23 & 0.24 \\
\hline rs739857 & 46254553 & - & - & $\mathrm{A} / \mathrm{C}$ & 0.40 & 0.14 & 0.11 \\
\hline rs 1235153 & 46396592 & P11 & intron 5 & $\mathrm{C} / \mathrm{T}$ & 0.05 & 0.01 & 0.00 \\
\hline *rs615382 & 48699178 & $R A C G A P 1$ & intron 2 & $\mathrm{C} / \mathrm{A}$ & 0.73 & 0.32 & 0.28 \\
\hline rs303810 & 50449515 & SCN8A & intron 18 & $\mathrm{~T} / \mathrm{C}$ & 0.49 & 0.48 & 0.47 \\
\hline rs585224 & 51209139 & - & - & $\mathrm{A} / \mathrm{G}$ & 0.51 & 0.28 & 0.23 \\
\hline rs 1683151 & 52232486 & ATF7 & intron 5 & $\mathrm{C} / \mathrm{G}$ & 0.51 & 0.11 & 0.09 \\
\hline rs 1867299 & 52616242 & - & - & $\mathrm{T} / \mathrm{C}$ & 0.50 & 0.30 & 0.33 \\
\hline rs 1078109 & 56272633 & $P I P 4 K 2 C$ & intron 2 & G/A & 0.07 & 0.01 & 0.01 \\
\hline rs1157239 & 63814994 & - & - & $\mathrm{G} / \mathrm{A}$ & 0.52 & 0.32 & 0.27 \\
\hline rs 343087 & 64547191 & $H M G A 2$ & intron 4 & $\mathrm{~A} / \mathrm{G}$ & 0.78 & 0.19 & 0.16 \\
\hline
\end{tabular}

* AIMs associated with PCa risk.

Table III. AIM association with PCa risk.

\begin{tabular}{|c|c|c|c|c|c|c|c|c|}
\hline SNP ID & Alleles & Gene & Wild-type allele & Risk allele & Co-Dominant & Dominant & Recessive & Log-additive \\
\hline rs989278 & $\mathrm{C}: \mathrm{G}$ & SOX5 & $\mathrm{C}$ & G & 0.66 & 0.36 & 0.63 & 0.4 \\
\hline *rs1993973 & G:A & $I V S$ & $\mathrm{G}$ & A & 0.0018 & 0.0076 & 0.0022 & 0.0004 \\
\hline rs1027089 & $\mathrm{C}: \mathrm{G}$ & IVS & $\mathrm{C}$ & $\mathrm{G}$ & 0.68 & 0.88 & 0.38 & 0.69 \\
\hline rs895964 & $\mathrm{G}: \mathrm{A}$ & ITPR2 & A & G & 0.32 & 0.92 & 0.15 & 0.65 \\
\hline rs1010096 & $\mathrm{C}: \mathrm{T}$ & $P P F I B P 1$ & $\mathrm{C}$ & $\mathrm{T}$ & 0.36 & 0.21 & 0.26 & 0.15 \\
\hline *rs1561131 & $\mathrm{C}: \mathrm{T}$ & IVS & $\mathrm{C}$ & $\mathrm{T}$ & 0.0052 & 0.14 & 0.022 & 0.62 \\
\hline *rs1843321 & $\mathrm{C}: \mathrm{T}$ & IVS & $\mathrm{C}$ & $\mathrm{T}$ & 0.074 & 0.078 & 0.059 & 0.025 \\
\hline *rs1963562 & $\mathrm{C}: \mathrm{T}$ & IVS & $\mathrm{C}$ & $\mathrm{T}$ & 0.052 & 0.031 & 0.53 & 0.07 \\
\hline rs870431 & $A: G$ & $I V S$ & A & $\mathrm{G}$ & 0.74 & 0.88 & 0.44 & 0.77 \\
\hline${ }^{\dagger} \mathrm{rs} 278906$ & $\mathrm{C}: \mathrm{T}$ & CNTN1 & $\mathrm{C}$ & $\mathrm{T}$ & - & - & - & - \\
\hline rs180438 & G:A & SLC $38 A 4$ & $\mathrm{G}$ & A & 0.77 & 0.47 & 0.85 & 0.54 \\
\hline rs739857 & $\mathrm{A}: \mathrm{C}$ & IVS & A & $\mathrm{C}$ & 0.54 & 0.35 & 0.75 & 0.48 \\
\hline †rs 1235153 & $\mathrm{C}: \mathrm{T}$ & ENDOU & $\mathrm{C}$ & $\mathrm{T}$ & - & - & - & - \\
\hline$*_{r s 615382}$ & $\mathrm{C}: \mathrm{A}$ & $R A C G A P 1$ & $\mathrm{C}$ & A & 0.04 & 0.23 & 0.012 & 0.04 \\
\hline rs303810 & $\mathrm{T}: \mathrm{C}$ & SCN8A & $\mathrm{T}$ & $\mathrm{C}$ & 0.42 & 0.44 & 0.44 & 0.95 \\
\hline rs585224 & $A: G$ & $I V S$ & A & $\mathrm{G}$ & 0.052 & 0.016 & 0.6 & 0.033 \\
\hline rs1683151 & $\mathrm{G}: \mathrm{C}$ & ATF7 & G & $\mathrm{C}$ & 0.92 & 0.99 & 0.69 & 0.92 \\
\hline rs1867299 & $\mathrm{T}: \mathrm{C}$ & $I V S$ & $\mathrm{~T}$ & $\mathrm{C}$ & 0.7 & 0.89 & 0.46 & 0.82 \\
\hline rs 1078109 & $\mathrm{G}: \mathrm{A}$ & $P I P 4 K 2 C$ & G & A & 0.32 & 0.25 & 0.18 & 0.18 \\
\hline rs1157239 & $\mathrm{G}: \mathrm{A}$ & IVS & $\mathrm{G}$ & A & 0.43 & 0.53 & 0.21 & 0.31 \\
\hline rs343087 & $\mathrm{A}: \mathrm{G}$ & $H M G A 2$ & A & $\mathrm{G}$ & 0.92 & 0.69 & 0.98 & 0.72 \\
\hline
\end{tabular}

*AIMs associated with PCa; all $p$-Values shown corrected for multiple comparisons. ${ }^{\dagger}$ AIMs with no associations with PCa under any genetic model

rs615382 under the co-dominant, recessive and log-additive models. Only AIM rs615382 is located within a genic region and lies within intron two of the RACGAPl gene.
Haplotype analyses. The haplotypes were constructed using fastPHASE v2.1 and are shown in Table IV. Three haplotypes 5 "GTCCC", 9 "ATTCT", and 11 "ACCCC" showed an 
Table IV. fastPHASE haplotype unadjusted association with PCa risk.

\begin{tabular}{lccccccc}
\hline & Haplotype & Controls & $\%$ & Cases & $\%$ & OR (95\% CI) & $p$-Value \\
\hline 1 & GCCCT & 57 & $19.0 \%$ & 42 & $13.4 \%$ & - \\
2 & GCCCC & 44 & $14.7 \%$ & 46 & $14.6 \%$ & $1.4(0.8-2.5)$ & 0.25 \\
3 & ACCCT & 29 & $9.7 \%$ & 13 & $4.1 \%$ & $0.6(0.3-1.3)$ & 0.26 \\
4 & GTCCT & 25 & $8.3 \%$ & 23 & $7.3 \%$ & $1.2(0.6-2.5)$ & 0.60 \\
5 & GTCCC & 12 & $4.0 \%$ & 27 & $8.6 \%$ & $3.1(1.4-6.7)$ & 0.01 \\
6 & ATTTC & 14 & $4.7 \%$ & 9 & $2.9 \%$ & $0.9(0.3-2.2)$ & 0.82 \\
7 & ATTCC & 24 & $8.0 \%$ & 27 & $8.6 \%$ & $1.5(0.8-3.0)$ & 0.23 \\
8 & ATCCT & 17 & $5.7 \%$ & 14 & $4.5 \%$ & $1.1(0.5-2.5)$ & 0.84 \\
9 & ATTCT & 6 & $2.0 \%$ & 26 & $8.3 \%$ & $5.9(2.2-15.6)$ & 0.0002 \\
10 & GTTCT & 9 & $3.0 \%$ & 9 & $2.9 \%$ & $1.4(0.5-3.4)$ & 0.61 \\
11 & ACCCC & 14 & $4.7 \%$ & 25 & $8.0 \%$ & $2.4(1.1-5.2)$ & 0.03 \\
Other* & & 49 & $16.3 \%$ & 53 & $16.9 \%$ & $1.5(0.8-2.6)$ & 0.20 \\
\hline
\end{tabular}

* Other refers to haplotypes inferred with a frequency of less than $1 \%$.

Table V. fastPHASE haplotype association with PCa adjusted for age and ancestry.

\begin{tabular}{|c|c|c|c|c|c|}
\hline \multirow[t]{2}{*}{ Haplotype } & & \multicolumn{2}{|c|}{ Age adjusted } & \multicolumn{2}{|c|}{ Age and Ancestry adjusted } \\
\hline & & OR $(95 \% \mathrm{CI})$ & $p$-Value & $\mathrm{OR}(95 \% \mathrm{CI})$ & $p$-Value \\
\hline 1 & GCCCT & - & - & - & - \\
\hline 2 & GCCCC & $1.98(0.96-4.07)$ & 0.0636 & $1.75(0.84-3.64)$ & 0.1361 \\
\hline 3 & ACCCT & $0.81(0.33-1.98)$ & 0.634 & $0.8(0.32-1.98)$ & 0.6298 \\
\hline 4 & GTCCT & $1.74(0.74-4.07)$ & 0.2016 & $1.75(0.74-4.15)$ & 0.2012 \\
\hline 5 & GTCCC & $3.97(1.57-10.05)$ & 0.0037 & $3.62(1.42-9.21)$ & $0.0070^{*}$ \\
\hline 6 & ATTTC & $0.69(0.17-2.82)$ & 0.6071 & $0.61(0.15-2.50)$ & 0.4907 \\
\hline 7 & ATTCC & $2.23(0.96-5.16)$ & 0.0620 & $2.36(1.0-5.54)$ & 0.05 \\
\hline 8 & ATCCT & $1.69(0.61-4.67)$ & 0.31 & $1.68(0.61-4.66)$ & 0.3176 \\
\hline 9 & ATTCT & $8.30(2.51-27.45)$ & 0.0005 & $7.89(2.37-26.31)$ & $0.0008^{*}$ \\
\hline 10 & GTTCT & $1.08(0.24-4.81)$ & 0.9230 & $0.92(0.21-4.14)$ & 0.9143 \\
\hline 11 & ACCCC & $4.62(1.03-4.33)$ & 0.0009 & $4.34(1.75-10.78)$ & $0.0016^{*}$ \\
\hline *Other & & $2.11(1.05-0.09)$ & 0.0408 & $1.9(0.92-3.95)$ & 0.0845 \\
\hline
\end{tabular}

*Other refers to haplotypes inferred with a frequency of less than $1 \%$.

association of haplotypes with risk for $\mathrm{PCa} \quad(\mathrm{OR}=3.1$; 95\% CI=1.4-6.7; $p=0.01, \mathrm{OR}=5.9 ; 95 \% \mathrm{CI}=2.2-15.6 ; p=0.0002$ and $\mathrm{OR}=2.4 ; 95 \% \mathrm{CI}=1.1-5.2 ; p=0.03$; respectively). After adjusting for age and ancestry, these three haplotypes remained significantly associated with PCa risk (Table V).

The search for alteration of regulatory mechanisms using Alibaba and HaploReg yielded the modification of a number of regulatory binding sites. The most notable being the disruption of a binding site for the notch signaling pathway regulated transcriptional modulator RBP-Jkappa in intron 2 of the RACGAP1 gene (Figure 1).

\section{Discussion}

Five AIMs were associated with PCa after the application of different genetic models as well as haplotypes constructed using them. The "ACCCC" haplotype showed a statistically significant association with $\mathrm{PCa}$ after adjusting for age and ancestry. Only one AIM in the haplotype is located within a genic region. SNP rs615382 is located in an intron of the proto-oncogene RACGAP1. RACGAP1, Rac GTPase activating protein (GAP) 1 , is under regulation of the Notch signaling pathway. SNP rs615382 disrupts the binding site for recombination signal binding protein for immunoglobulin kappa J (RBP-Jkappa) (44). RBP-Jkappa acts as a transcriptional repressor or activator when bound or unbound to Notch proteins respectively. Loss of the RBP-Jkappa binding site eliminates the ability of RBP-Jkappa to repress RACGAP1 transcription. GAPs bind activated forms of Rho GTPases and stimulate GTP hydrolysis. GAPs negatively regulate Rho-mediated signals and are involved in downstream signaling of Ras-like GTPases. 


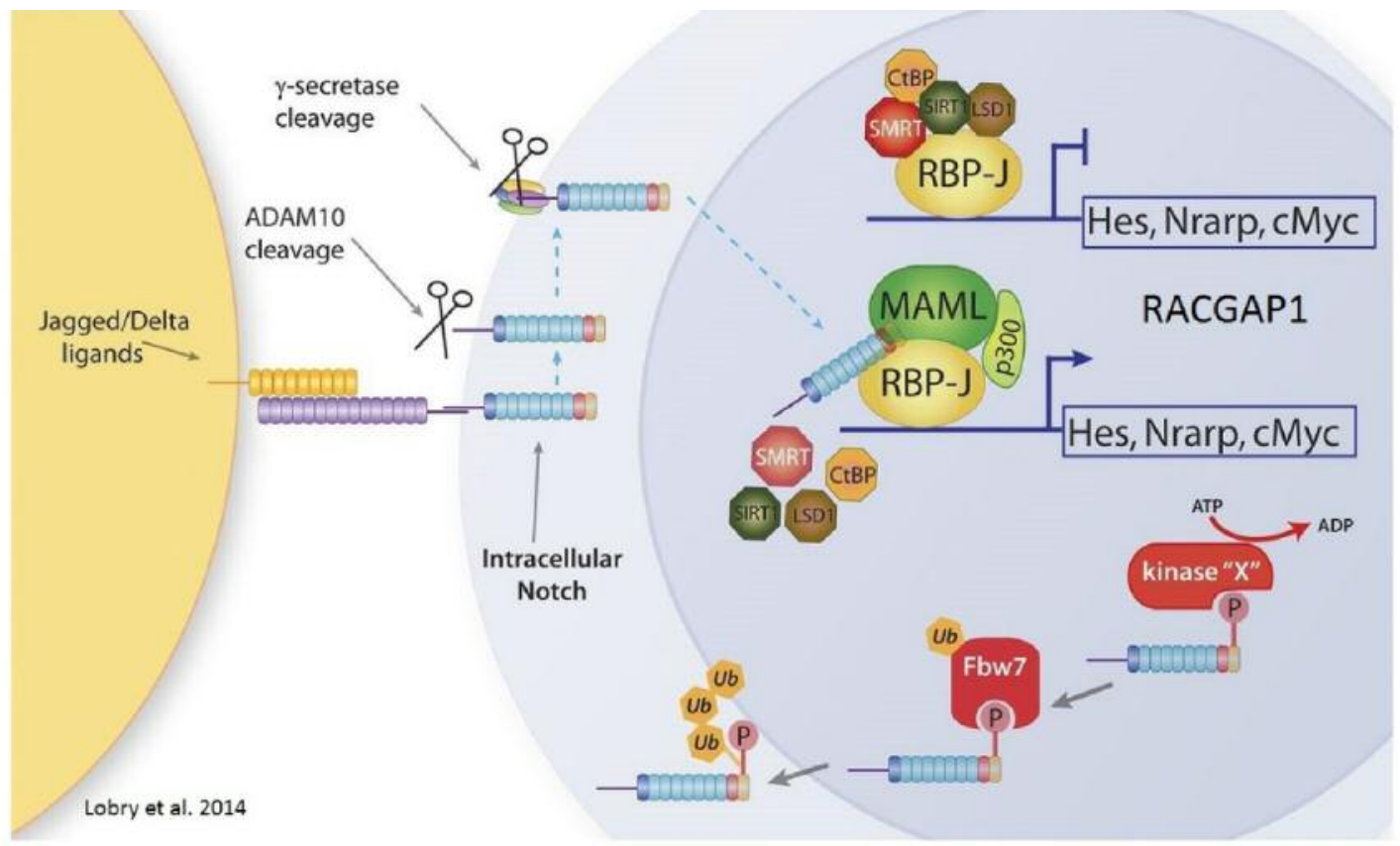

Figure 1. Adopted from Lobry et al. 2014. Mammal Notch canonical activation pathway. Cognate interaction between Notch receptors and Notch ligands (Jagged/Delta) triggers 2 consecutive proteolytic cleavages by the ADAM10 metalloprotease and the $\gamma$-secretase complex. This generates ICN, the signaling portion of the receptor, which enters the nucleus and displaces corepressors (SMRT and CtBP1) and recruits the coactivator MAML1 and the acetyltransferase p300. ICN activating complex is short-lived, and ICN gets phosphorylated on its PEST domain and subsequently ubiquitinated by Fbw7 and targeted for degradation by the proteasome. ADP: Adenosine diphosphate; ATP: adenosine triphosphate.

RACGAP1 has been implicated in multiple malignancies including breast, gastric, hepatocellular, and non small-cell lung carcinoma (45-47). Up-regulation of RACGAP1 has been associated with early recurrence of hepatocellular carcinoma and is overexpressed in non small-cell lung and luminal breast cancer. RACGAP1 expression was also correlated with tumor progression and poor prognosis in gastric cancer. To date, there have been no reports of RACGAP association with PCa.

We understand that cancer results from an accumulation of genetic mutations. We also understand that although many cancers share common mutations, they are discrete entities that are capable of evolving over time. Loss of RACGAP1 regulation may be one of the mutations acquired in the development of PCa. A larger study of African American tumor samples would reveal whether RACGAP1 overexpression is a common feature of $\mathrm{PCa}$.

\section{Acknowledgements}

This project was supported in part by the National Institute of Minority Health Disparities of the National Institutes of Health under Award Number G12MD007597. The content is solely the responsibility of the Authors and does not necessarily represent the official views of the National Institutes of Health.

\section{References}

1 Parkin DM, Bray F, Ferlay J and Pisani P: Global Cancer Statistics, 2002. CA Cancer J Clin 55: 74-108, 2005.

2 Grönberg H: Prostate cancer epidemiology. Lancet 361: 859864, 2003.

3 Jemal A Tiwari RC, Murray T, Ghafoor A, Samuels A, Ward E, Fuer EJ and Thun MJ: Cancer Statistics 2004. CA Cancer J Clin 54: 8-29, 2004.

4 Jemal A, Murray T, Ward E, Samuels A, Tiwari RC, Ghafoor A, Fuer EJ and Thun MJ: Cancer Statistics 2005. CA Cancer J Clin 55: 10-30, 2005.

5 Jemal A, Siegel R, Ward E, Murray T, Xu J, Smigal C and Thun MJ: Cancer Statistics 2006. CA Cancer J Clin 56: 106-130, 2006.

6 Jemal A, Siegel R, Ward E, Murray T, Xu J, Smigal C and Thun MJ: Cancer Statistics 2007. CA Cancer J Clin 57: 43-66, 2007.

7 Jemal A, Siegel R, Ward E, Hao Y, Xu J, Murray T and Thun MJ: Cancer Statistics 2008. CA Cancer J Clin 58: 71-96, 2008.

8 Jemal A, Siegel R, Ward E, Hao Y, Xu J, Murray T and Thun MJ: Cancer Statistics 2009. CA Cancer J Clin 59: 225-249, 2009.

9 U.S. Cancer Statistics Working Group. United States Cancer Statistics: 2002 Incidence and Mortality. Atlanta: U.S. Department of Health and Human Services, Centers for Disease Control and Prevention and National Cancer Institute, 2005.

10 State Cancer Profiles: www.statecancerprofiles.cancer.gov 
11 Glass AS, Cary KC and Cooperberg MR: Risk-Based Prostate Cancer Screening: Who and How? Curr Urol Rep 14: 192-198, 2013.

12 Richardson LD, Norris M: Access to health and health care: how race and ethnicity matter. Mt Sinai J Med 77: 166-177, 2010.

13 Rodríguez C, Calle EE, Miracle-McMahill HL, Tatham LM, Wingo PA, Thun MJ and Heath CW Jr.: Family history and risk of fatal prostate cancer. Epidemiology 8: 653-657, 1997.

14 Bishop TD and Kiemeney LA: Family studies of the evidence for genetic susceptibility to prostate cancer. Semin Cancer Biol 8: 45-51, 1997.

15 Eeles RA, Durocher F, Edwards S, Teare D, Badzioch M, Hamoudi R, Gill S, Biggs P, Dearnaley D, Ardern-Jones A, Dowe A, Shearer R, McLellan DL, Norman RL, Ghadirian P, Aprikian A, Ford D, Amos C, King TM, Labrie F, Simard J, Narod SA, Easton D and Foulkes WD: Linkage analysis of chromosome 1q markers in 136 prostate cancer families. The Cancer Research Campaign/British Prostate Group U.K. Familial Prostate Cancer Study Collaborators. Am J Hum Genet 62: 653-658, 1998.

16 Narod S: Genetic epidemioogy of prostate cancer. Biochim Biophys Acta 1423: F1-F13, 1998.

17 Jarvik GP, Stanford JL, Goode EL, McIndoe R, Kolb S, Gibbs M, Hood L and Ostrander EA: Confirmation of prostate cancer susceptibility genes using high-risk families. J Natl Cancer Inst Monogr 26: 81-87, 1999.

18 Cui J, Staples MP, Hopper JL, English DR, McCredie MR and Giles GG: Segregation analyses of 1,476 population-based Australian families affected by prostate cancer. Am J Hum Genet 68: 1207-1218, 2001.

19 Casey G, Neville PJ, Liu X, Plummer SJ, Cicek MS, Krumroy LM, Curran AP, McGreevy MR, Catalona WJ, Klein EA and Witte JS: Podocalyxin variants and risk of prostate cancer and tumor aggressiveness. Hum Mol Genet 15: 735-741, 2006.

20 Johanneson B, McDonnell SK, Karyadi DM, Quignon P, McIntosh L, Riska SM, FitzGerald LM, Johnson G, Deutsch K, Williams G, Tillmans LS, Stanford JL, Schaid DJ, Thibodeau SN and Ostrander EA: Family-based association analysis of 42 hereditary prostate cancer families identifies the Apolipoprotein L3 region on chromosome $22 \mathrm{q} 12$ as a risk locus. Hum Mol Genet 19: 3852-3862, 2010

21 Irvine RA, Yu MC, Ross RK and Coetzee GA: The CAG and GGC microsatellites of the androgen receptor gene are in linkage disequilibrium in men with prostate cancer. Cancer Res 55: 1937-1940, 1995.

22 Grönberg H, Damber L and Damber JE: Studies of genetic factors in prostate cancer in a twin population. J Urol 152: 1484-1487, 1994.

23 Ahlbom A, Lichtenstein P, Malmström H, Feychting M, Hemminki $\mathrm{K}$ and Pedersen NL: Cancer in twins: genetic and nongenetic familial risk factors. J Natl Cancer Inst 89: 287-293, 1997.

24 Lichtenstein P, Holm NV, Verkasalo PK, Iliadou A, Kaprio J, Koskenvuo M, Pukkala E, Skytthe A and Hemminki K: Environmental and heritable factors in the causation of cancer-analyses of cohorts of twins from Sweden, Denmark, and Finland. N Engl J Med 343: 78-85, 2000.

25 Kittles RA, Chen W, Panguluri RK, Ahaghotu C, Jackson A, Adebamowo CA, Griffin R, Williams T, Ukoli F, AdamsCampbell L, Kwagyan J, Isaacs W, Freeman V and Dunston GM: CYP3A4-V and prostate cancer in African Americans: causal or confounding association because of population stratification? Hum Genet 110: 553-560, 2002.
26 Winkler CA, Nelson GW and Smith MW: Admixture mapping comes of age: Annu Rev Genomics Hum Genet 11: 65-89, 2010.

27 Smith MW, Patterson N, Lautenberger JA, Truelove AL, McDonald GJ, Waliszewska A, Kessing BD, Malasky MJ, Scafe C, Le E, De Jager PL, Mignault AA, Yi Z, De The G, Essex M, Sankale JL, Moore JH, Poku K, Phair JP, Goedert JJ, Vlahov D, Williams SM, Tishkoff SA, Winkler CA, De La Vega FM, Woodage T, Sninsky JJ, Hafler DA, Altshuler D, Gilbert DA, O'Brien SJ and Reich D: A high-density admixture map for disease gene discovery in african americans. Am J Hum Genet 74: 1001-1013, 2004.

28 Freedman ML, Haiman CA, Patterson N, McDonald GJ, Tandon A, Waliszewska A, Penney K, Steen RG, Ardlie K, John EM, Oakley-Girvan I, Whittemore AS, Cooney KA, Ingles SA, Altshuler D, Henderson BE and Reich D: Admixture mapping identifies $8 \mathrm{q} 24$ as a prostate cancer risk locus in AfricanAmerican men. Proc Natl Acad Sci USA 103: 14068-14073, 2006.

29 Bonilla C, Hooker S, Mason T, Bock CH and Kittles RA: Prostate cancer susceptibility Loci identified on chromosome 12 in African Americans. PLoS One 6: e16044, 2011.

30 Teerlink CC, Thibodeau SN, McDonnell SK et al: Association analysis of 9,560 prostate cancer cases from the International Consortium of Prostate Cancer Genetics confirms the role of reported prostate-cancer associated SNPs for familial disease. Human Genet 133: 347-356, 2014.

31 Yeager M, Orr N, Hayes RB, Jacobs KB, Kraft P, Wacholder S, Minichiello MJ, Fearnhead P, Yu K, Chatterjee N, Wang Z, Welch R, Staats BJ, Calle EE, Feigelson HS, Thun MJ, Rodriguez C, Albanes D, Virtamo J, Weinstein S, Schumacher FR, Giovannucci E, Willett WC, Cancel-Tassin G, Cussenot O, Valeri A, Andriole GL, Gelmann EP, Tucker M, Gerhard DS, Fraumeni JF Jr, Hoover R, Hunter DJ, Chanock SJ and Thomas G: Genome-wide association study of prostate cancer identifies a second risk locus at 8q24. Nat Genet 39: 645-649, 2007.

32 Nam RK, Zhang WW, Loblaw DA, Klotz LH, Trachtenberg J, Jewett MA, Stanimirovic A, Davies TO, Toi A, Venkateswaran V, Sugar L, Siminovitch KA and Narod SA: A genome-wide association screen identifies regions on chromosomes 1q25 and $7 \mathrm{p} 21$ as risk loci for sporadic prostate cancer. Prostate Cancer Prostatic Dis 11: 241-246, 2008.

33 Thomas G, Jacobs KB, Yeager M, Kraft P, Wacholder S, Orr N, Yu K, Chatterjee N, Welch R, Hutchinson A, Crenshaw A, Cancel-Tassin G, Staats BJ, Wang Z, Gonzalez-Bosquet J, Fang J, Deng X, Berndt SI, Calle EE, Feigelson HS, Thun MJ, Rodriguez C, Albanes D, Virtamo J, Weinstein S, Schumacher FR, Giovannucci E, Willett WC, Cussenot O, Valeri A, Andriole GL, Crawford ED, Tucker M, Gerhard DS, Fraumeni JF Jr., Hoover R, Hayes RB, Hunter DJ and Chanock SJ: Multiple loci identified in a genome-wide association study of prostate cancer. Nat Genet 40: 310-315, 2008.

34 Christensen GB, Baffoe-Bonnie AB, George A, Powell I, BaileyWilson JE, Carpten JD, Giles GG, Hopper JL, Severi G, English DR, Foulkes WD, Maehle L, Moller P, Eeles R, Easton D, Badzioch MD, Whittemore AS, Oakley-Girvan I, Hsieh CL, Dimitrov L, Xu J, Stanford JL, Johanneson B, Deutsch K, McIntosh L, Ostrander EA, Wiley KE, Isaacs SD, Walsh PC, Isaacs WB, Thibodeau SN, McDonnell SK, Hebbring S, Schaid DJ, Lange EM, Cooney KA, Tammela TL, Schleutker J, Paiss T, Maier C, Grönberg H, Wiklund F, Emanuelsson M, Farnham JM, 
Cannon-Albright LA and Camp NJ; International Consortium for Prostate Cancer Genetics: Genome-wide linkage analysis of 1,233 prostate cancer pedigrees from the International Consortium for Prostate Cancer Genetics using novel sumLINK and sumLOD analyses. Prostate 70: 735-744, 2010.

35 Batra J, Lose F, O'Mara T, Marquart L, Stephens C, Alexander K, Srinivasan S, Eeles RA, Easton DF, Al Olama AA, Kote-Jarai Z, Guy M, Muir K, Lophatananon A, Rahman AA, Neal DE, Hamdy FC, Donovan JL, Chambers S, Gardiner RA, Aitken J, Yaxley J, Kedda MA, Clements JA and Spurdle AB: Association between Prostinogen (KLK15) genetic variants and prostate cancer risk and aggressiveness in Australia and a meta-analysis of GWAS data. PLoS One 6: e26527, 2011.

36 Yeager M, Xiao N, Hayes RB, Bouffard P, Desany B, Burdett L, Orr N, Matthews C, Qi L, Crenshaw A, Markovic Z, Fredrikson KM, Jacobs KB, Amundadottir L, Jarvie TP, Hunter DJ, Hoover R, Thomas G, Harkins TT and Chanock SJ: Comprehensive resequence analysis of a $136 \mathrm{~kb}$ region of human chromosome $8 \mathrm{q} 24$ associated with prostate and colon cancers. Hum Genet 124: 161-170, 2008.

37 Yin M, Wei S and Wei Q: Vitamin D Receptor Genetic Polymorphisms and Prostate Cancer Risk: A Meta-analysis of 36 Published Studies. Int J Clin Experiment Med 2: 159-175, 2009.

38 Al Olama AA, Kote-Jarai Z, Berndt SI, Conti DV, Schumacher F, Han Y, Benlloch S, Hazelett DJ, Wang Z, Saunders E, Leongamornlert D, Lindstrom S, Jugurnauth-Little S, Dadaev T, Tymrakiewicz M, Stram DO, Rand K, Wan P, Stram A, Sheng X, Pooler LC, Park K, Xia L, Tyrer J, Kolonel LN, Le Marchand L, Hoover RN, Machiela MJ, Yeager M, Burdette L, Chung CC, Hutchinson A, Yu K, Goh C, Ahmed M, Govindasami K, Guy M, Tammela TL, Auvinen A, Wahlfors T, Schleutker J, Visakorpi T, Leinonen KA, Xu J, Aly M, Donovan J, Travis RC, Key TJ, Siddiq A, Canzian F, Khaw KT, Takahashi A, Kubo M, Pharoah P, Pashayan N, Weischer M, Nordestgaard BG, Nielsen SF, Klarskov P, Røder MA, Iversen P, Thibodeau SN, McDonnell SK, Schaid DJ, Stanford JL, Kolb S, Holt S, Knudsen B, Coll AH, Gapstur SM, Diver WR, Stevens VL, Maier C, Luedeke M, Herkommer K, Rinckleb AE, Strom SS, Pettaway C, Yeboah ED, Tettey Y, Biritwum RB, Adjei AA, Tay E, Truelove A, Niwa S, Chokkalingam AP, Cannon-Albright L, Cybulski C, Wokołorczyk D, Kluźniak W, Park J, Sellers T, Lin HY, Isaacs WB, Partin AW, Brenner H, Dieffenbach AK, Stegmaier C, Chen C, Giovannucci EL, Ma J, Stampfer M, Penney KL, Mucci L, John EM, Ingles SA, Kittles RA, Murphy AB, Pandha H, Michael A, Kierzek AM, Blot W, Signorello LB, Zheng W, Albanes D, Virtamo J, Weinstein S, Nemesure B, Carpten J, Leske C, Wu SY, Hennis A, Kibel AS, Rybicki BA, Neslund-Dudas C, Hsing AW, Chu L, Goodman PJ, Klein EA, Zheng SL, Batra J, Clements J, Spurdle A, Teixeira MR, Paulo P, Maia S, Slavov C, Kaneva R, Mitev V, Witte JS, Casey G, Gillanders EM, Seminara D, Riboli E, Hamdy FC, Coetzee GA, Li Q, Freedman ML, Hunter DJ, Muir K, Gronberg H, Neal DE, Southey M, Giles GG, Severi G; Breast and Prostate Cancer Cohort Consortium (BPC3); PRACTICAL (Prostate Cancer Association Group to Investigate Cancer-Associated Alterations in the Genome) Consortium; COGS (Collaborative Oncological Gene-environment Study) Consortium; GAME-ON/ELLIPSE Consortium, Cook MB, Nakagawa H, Wiklund F, Kraft P, Chanock SJ, Henderson BE, Easton DF, Eeles RA and Haiman CA: A metaanalysis of 87,040 individuals identifies 23 new susceptibility loci for prostate cancer. Nature Genet 46: 1103-1109, 2014.
39 Parikh H, Deng Z, Yeager M, Boland J, Matthews C, Jia J, Collins I, White A, Burdett L, Hutchinson A, Qi L, Bacior JA, Lonsberry V, Rodesch MJ, Jeddeloh JA, Albert TJ, Halvensleben HA, Harkins TT, Ahn J, Berndt SI, Chatterjee N, Hoover R, Thomas G, Hunter DJ, Hayes RB, Chanock SJ and Amundadottir L: A comprehensive resequence analysis of the KLK15-KLK3-KLK2 locus on chromosome 19q13.33. Hum Genet 127: 91-99, 2010.

40 Ricks-Santi LJ, Apprey V, Mason T, Wilson B, Abbas M, Hernandez W, Hooker S, Doura M, Bonney G, Dunston G, Kittles $\mathrm{R}$ and Ahaghotu $\mathrm{C}$ : Identification of genetic risk associated with prostate cancer using ancestry informative markers. Prost Cancer Prostatic Dis 15: 359-364, 2012.

41 Scheet P and Stephens M: A fast and flexible statistical model for large-scale population genotype data: applications to inferring missing genotypes and haplotypic phase. Am J Hum Genet 78: 629-644, 2006.

42 Falush D, Stephens M and Pritchard JK: Inference of population structure using multilocus genotype data: linked loci and correlated allele frequencies. Genetics 164: 1567-1587, 2006.

43 Hancock AM, Witonsky DB, Ehler E, Alkorta-Aranburu G, Beall C, Gebremedhin A, Sukernik R, Utermann G, Pritchard J, Coop $\mathrm{G}$ and Di Rienzo A: Colloquium paper: human adaptations to diet, subsistence, and ecoregion are due to subtle shifts in allele frequency. Proc Natl Acad Sci USA 107: 8924-8930, 2010.

44 Akey JM, Zhang G, Zhang K, Jin L and Shriver MD: Interrogating a high-density SNP map for signatures of natural selection. Genome Res 12: 1805-1814, 2002.

45 RACGAP1 [Internet]. Bethesda (MD): National Library of Medicine (US), National Center for Biotechnology Information; 2004 - [cited 2017 Jul 13]. Available from: https:// www.ncbi.nlm.nih.gov/gene/29127

46 Milde-Langosch K, Karn T, Müller V, Witzel I, Rody A, Schmidt $M$ and Wirtz RM: Validity of the proliferation markers Ki67, TOP2A, and RacGAP1 in molecular subgroups of breast cancer. Breast Cancer Res Treat 137: 57-67, 2013.

47 Wang SM, Ooi LL and Hui KML: Upregulation of Rac GTPaseactivating protein 1 is significantly associated with the early recurrence of human hepatocellular carcinoma. Clin Cancer Res 17: 6040-6051, 2011.

48 Liang Y, Liu M, Wang P, Ding X and Cao Y: Analysis of 20 genes at chromosome band 12q13: RACGAP1 and MCRS1 overexpression in nonsmall-cell lung cancer. Genes Chrom Cancer 52: 305-315, 2013.
Received July 16, 2017

Revised November 16, 2017

Accepted November 20, 2017 